\title{
W POSZUKIWANIU PRZYRODNICZEGO, FILOZOFICZNEGO I TEOLOGICZNEGO OBRAZU WSZECHŚWIATA. SYLWETKA NAUKOWA KSIĘDZA GRZEGORZA BUGAJAKA
}

\begin{abstract}
Streszczenie. W artykule przedstawiono życiorys i najważniejsze dokonania naukowe ks. dr hab. Grzegorza Bugajaka (1966-2020), prof. UKSW, związanego z Wydziałem Filozofii Chrześcijańskiej ATK/UKSW. Ks. Bugajak zostawił po sobie duży i interesujący dorobek naukowy, koncentrujący się wokół problemów z zakresu filozofii przyrody, filozofii nauk przyrodniczych i relacji między naukami przyrodniczymi a teologią. Jego prace stanowią znaczny wkład w rozwój filozofii.
\end{abstract}

Słowa kluczowe: Grzegorz Bugajak; filozofia przyrody; nauka a religia

1. Życiorys. 2. Zagadnienia metateoretyczne. 3. Węzłowe problemy filozofii przyrody. 4. Relacje między nauką a religią.

\section{1. ŻYCIORYS}

Grzegorz Bugajak urodził się 6 października 1966 r. w Łodzi Dzieciństwo spędził w Jędrzejowie, Biłgoraju (tu przyjął I Komunię św.) i w Łodzi (od piątej klasy związany był z kościołem klasztornym sióstr Matki Bożej Miłosierdzia w Łodzi-Rudzie). W Łodzi ukończył w 1985 r. liceum ogólnokształcące i wstąpił do Wyższego Seminarium Duchownego. Wraz z formacją duchową w Seminarium odbywał studia teologiczne na Wydziale Teologicznym Akademii Teologii Katolickiej w Warszawie, zakończone w 1992 r. uzyskaniem stopnia magistra teologii na podstawie pracy: Przyczynowośc w mechanice

1 W niniejszym opracowaniu wykorzystałam autoreferat Grzegorza Bugajaka przedstawiony przez niego w procesie habilitacyjnym. 
kwantowej w ujęciu Davida Bohma. Opiekunem pracy był ks. dr hab. Bogdan Bakies, a recenzentem ks. dr hab. Józef M. Dołęga.

13 czerwca 1992 roku w Łodzi Grzegorz Bugajak został wyświęcony na kapłana i skierowany jako wikariusz do parafii Najświętszego Serca Jezusa w Kurowicach. Następnie, już pracując na ATK, pomagał duszpastersko w parafii św. Andrzeja Boboli w Łodzi-Nowosolnej. W swoim życiu łączył w harmonijny sposób działalność naukową z duszpasterską. Znalazło to również swój wyraz w podejmowanych przez niego problemach filozoficznych. Zainteresowania filozofią sprawiły, że w 1993 r. został skierowany przez ks. arcybiskupa Władysława Ziółka na studia filozoficzne na Wydział Filozofii Chrześcijańskiej ATK w Warszawie. Bugajak studiował tu w latach 1993-1996 na specjalności filozofia przyrody. Specyfika uprawiania tej dyscypliny filozoficznej na ATK, wyrażająca się w łączeniu jej z wynikami nauk przyrodniczych, leżała zapewne u źródeł decyzji Bugajaka, by w latach 1997-2002 studiować fizykę na Wydziale Fizyki Uniwersytetu Warszawskiego.

W 1995 r. Bugajak został zatrudniony w Katedrze Metodologii Nauk Systemowo-Informacyjnych na Wydziale Filozofii Chrześcijańskiej ATK w Warszawie najpierw jako asystent-stażysta, a następnie jako asystent. Dzięki temu mógł prowadzić badania w dziedzinie filozofii i przygotowywać rozprawę doktorską. W roku 1999 uzyskał stopień doktora nauk humanistycznych w zakresie filozofii na $\mathrm{Wy}$ dziale Filozofii Chrześcijańskiej ATK, broniąc pracy pt. Epistemologiczny status koncepcji Wielkiego Wybuchu i jej flozoficzne implikacje. Promotorem pracy była prof. dr hab. Anna Latawiec, a recenzentami ks. prof. dr hab. Mieczysław Lubański i prof. dr hab. Michał Tempczyk.

Po uzyskaniu stopnia doktora nauk humanistycznych został zatrudniony w roku 1999 w tej samej Katedrze jako adiunkt. Równolegle wykładał filozofię przyrody w Wyższym Seminarium Duchownym w Łodzi, w punkcie konsultacyjnym UKSW w Łodzi, w Instytucie Teologicznym w Łodzi, w Wyższym Seminarium Duchownym oo. 
Franciszkanów w Łodzi-Łagiewnikach, w Wyższym Seminarium Duchownym Księży Salezjanów w Łodzi. W latach 2006-2010 pracował na stanowisku adiunkta w Międzyuczelnianej Katedrze Nauk Humanistycznych Uniwersytetu Medycznego w Łodzi.

W 2013 roku Bugajak uzyskał stopień doktora habilitowanego nauk humanistycznych w zakresie filozofii na podstawie cyklu publikacji zatytułowanego przez niego Węztowe zagadnienia filozofii przyrody i rola tej dyscypliny w ksztattowaniu relacji nauka - teologia, oraz innego dorobku naukowego. Recenzentami w przewodzie byli: ks. dr hab. Janusz Mączka, ks. dr hab. Wiesław Dyk i dr hab. Anna Lemańska. W roku 2014 Bugajak został mianowany profesorem UKSW.

Grzegorz Bugajak pełnił wiele funkcji na swej macierzystej Uczelni, m.in. był członkiem komisji senackich, pełnomocnikiem Rektora UKSW ds. wdrożenia Uniwersyteckiego Systemu Obsługi Studiów w UKSW, członkiem Rady Uniwersyteckiego Centrum ds. Informatyzacji. W 2016 roku objął funkcję dyrektora Instytutu Filozofii UKSW. Był także członkiem krajowych i międzynarodowych towarzystw naukowych: od 1996 r. Polskiego Towarzystwa Filozoficznego, od 1997 European Society for the Study of Science and Theology (ESSSAT), w którym dwukrotnie był wybierany do Zarządu, od 2007 r. Słowackiego Towarzystwa Filozoficznego. Przez wiele lat był członkiem Zarządu Sekcji Filozofii Przyrody i Nauk Przyrodniczych PTF.

Bugajak uczestniczył w ponad dziewięćdziesięciu międzynarodowych i krajowych konferencjach i sympozjach, w większości czynnie. Częstokroć był zapraszany przez organizatorów konferencji do wygłoszenia referatu. Sam również organizował lub współorganizował konferencje lub warsztaty naukowe, w szczególności interdyscyplinarne warsztaty, stanowiące forum wymiany myśli i opinii dotyczących swoistości człowieka. Ich owocem jest seria książek 
współredagowanych przez niego razem z ks. Jackiem Tomczykiem². Bugajak uzyskał trzy granty przyznane przez organizacje i uczelnie zagraniczne: Center for Science and Theology, Berkeley (współpracownicy: R. Ressler - USA, P. Pavlovic - Belgia); Elon University (USA) i Universitet Interdisciplinaire de Paris (Francja); The International Society for Science and Religion.

Ważne pole działalności Grzegorza Bugajaka stanowiła praca w redakcjach czasopism naukowych. Od 1997 r. był Sekretarzem Redakcji Studia Philosophiae Christianae. Dzięki jego zaangażowaniu i wysiłkom czasopismo jest cenionym periodykiem wśród publikacji filozoficznych. Od 2006 r. był członkiem Advisory Board serii wydawniczych Studies in Science and Theology (SSTh) oraz Issues in Science and Theology (IST), związanych z ESSSAT.

Bugajak był cenionym przez studentów wykładowcą akademickim. Prowadził zajęcia dydaktyczne: wykłady kursoryczne $z$ kosmofilozofii, podstaw filozofii nauki, filozoficznych aspektów fizyki współczesnej, filozofii przyrody oraz wykłady monograficzne z filozofii kosmologii i z zagadnień relacji nauka - teologia. Należy zaznaczyć, że prowadził również wykłady w języku angielskim. Był opiekunem i recenzentem kilkunastu prac magisterskich i licencjackich. Był również popularyzatorem wiedzy filozoficznej. Opublikował kilka artykułów popularno-naukowych ${ }^{3}$, występował z odczytami m.in. w PRSU Veritas w Londynie, w KIK w Zgierzu, brał udział

2 Kontrowersje wokół początków człowieka, red. G. Bugajak, J. Tomczyk, Księgarnia św. Jacka, Katowice 2007; W poszukiwaniu swoistości człowieka, red. G. Bugajak, J. Tomczyk, Wydawnictwo UKSW, Warszawa 2008; Swoistość człowieka? Język, red. G. Bugajak, J. Tomczyk, Wydawnictwo UKSW, Warszawa 2008; Swoistość człowieka? Rozumność, red. G. Bugajak, J. Tomczyk, Wydawnictwo UKSW, Warszawa 2009.

3 M.in.: G. Bugajak, Nowa fizyka, Posłaniec 139(2010)1, 52-53; Tenże, W chwili zero, Posłaniec 139(2010)2, 48-49; Tenże, Czy Pan Bóg rzeczywiście stworzył świat?, w: Wierzyć i rozumieć, red. G. Dziewulski, M. Marczak, A. Perzyński, J. Wolski, Archidiecezjalne Wydawnictwo Łódzkie, Łódź 2013, 45-48; Tenże, Skąd wziął się człowiek?, w: Wierzyć i rozumieć, dz. cyt., 49-52; Czy ludzie wierzący moga uznawać teorię ewolucji?, w: Wierzyć i rozumieć, dz. cyt., 53-56. 
w audycjach telewizyjnych i radiowych. Za swoją działalność został odznaczony medalem Komisji Edukacji Narodowej oraz Medalem Brązowym za Długoletnią Służbę.

Ks. Bugajak zmarł nagle 17 maja 2020 r. w Łodzi. W kościele parafialnym pod wezwaniem Świętego Józefa Oblubieńca Najświętszej Maryi Panny w Łodzi-Rudzie - jego rodzinnej parafii - w przeddzień pogrzebu została odprawiona msza św. w jego intencji. Przewodniczył jej ks. bp senior Władysław Ziółek, który na początku liturgii wygłosił krótkie wspomnienie o Zmarłym. Msza święta pogrzebowa została odprawiona 22 maja w tym samym kościele. Liturgii przewodniczył ksiądz arcybiskup Grzegorz Ryś. Ks. Bugajak został pochowany na cmentarzu w Łodzi-Rudzie. Ceremonii pogrzebowej przewodniczył również ks. abp Ryś. W pogrzebie oprócz pracowników UKSW wzięli udział przedstawiciele Wydziału Filozofii Katolickiego Uniwersytetu Lubelskiego Jana Pawła II, Akademii Ignatianum w Krakowie oraz Sekcji Filozofii Przyrody i Nauk Przyrodniczych Polskiego Towarzystwa Filozoficznego.

Grzegorz Bugajak zostawił po sobie duży i interesujący dorobek naukowy, koncentrujący się wokół problemów z zakresu filozofii przyrody, filozofii nauk przyrodniczych i relacji między naukami przyrodniczymi a teologią. Jego prace stanowią znaczny wkład w rozwój filozofii.

\section{ZAGADNIENIA METATEORETYCZNE}

Prezentację poglądów filozoficznych ks. Grzegorza Bugajaka warto rozpocząć od przedstawienia jego poglądów, dotyczących zagadnień metaprzedmiotowych, w szczególności podzielanej przez niego koncepcji uprawiania filozofii przyrody. Studia na ATK i żywa w tym środowisku filozofów przyrody tradycja rozumienia tej dyscypliny filozoficznej niewątpliwie wywarly istotny wpływ na poglądy $\mathrm{Bu}-$ gajaka, który pozostał wierny wizji uprawiania filozofii przyrody 
stworzonej przez Kazimierza Kłósaka ${ }^{4}$, choć nie przejął bezkrytycznie wszystkich jego poglądów.

Bugajak włączył się w dyskusje toczone wśród polskich filozofów przyrody na przełomie XX i XXI wieku na temat istnienia i statusu filozofii przyrody. Mimo rozbudowanych nauk przyrodniczych mających tendencje do zawłaszczania coraz to nowych obszarów badań mieszczących się niegdyś w domenie filozofii, Bugajak widzi sens uprawiania refleksji filozoficznej nad przyrodą, choć nie niesie to za sobą żadnego praktycznego pożytku. Wydaje się, że przyjmuje, iż „,filozofia przyrody jest teorią świata materialnego, czyli rzeczywistości dostępnej w poznaniu zmysłowym (...), a jej celem jest zbudowanie ontologii tego świata, to jest określenie natury (istoty), struktury i właściwości bytów materialnych" 5 . Uzasadniając konieczność istnienia filozofii przyrody, Bugajak podaje przykładowe pytania, na które nauki przyrodnicze nigdy nie będą w stanie odpowiedzieć: „czym jest przestrzeń i czas, czy w świecie możliwe są zdarzenia czysto przypadkowe, czym jest życie”. Następnie sam już na płaszczyźnie przedmiotowej próbuje udzielać na nie odpowiedzi.

Jednym z ważnych problemów, dotyczących statusu filozofii przyrody jest kwestia wykorzystywania wyników nauk przyrodniczych w filozofii. Bugajak widzi taką konieczność - w pełni zgadza się w tym zakresie z Kłósakiem - choć jednocześnie dostrzega cenę, jaką trzeba za to zapłacić, a mianowicie tak uprawiana filozofia przyrody "nie realizuje ideału philosophia perennis", gdyż zmiany teorii naukowych będą wymuszać zmiany koncepcji filozoficznych. W tym kon-

4 Koncepcję uprawiania filozofii przyrody zawarł Kazimierz Kłósak w książce podsumowującej jego przemyślenia: K. Kłósak, Z teorii i metodologii filozofii przyrody, Księgarnia św. Wojciecha, Poznań 1980.

5 G. Bugajak, Filozofia przyrody a spór o status poznawczy teorii naukowych: Czy filozof przyrody może być realistą?, w: Filozoficzne i naukowo-przyrodnicze elementy obrazu świata, t. 7, red. A. Latawiec, G. Bugajak, Wydawnictwo UKSW, Warszawa 2008, 80.

6 G. Bugajak, O luksusie filozofowania, Roczniki Filozoficzne 54(2006)1, 345.

7 Tenże, Filozofia przyrody a spór o status poznawczy teorii naukowych, dz. cyt., 83. 
tekście Bugajak stawia ważne pytanie: czy filozof przyrody musi być realistą naukowym. Przywołuje dobrze znany podział koncepcji na temat statusu teorii przyrodniczych na realistyczne i antyrealistyczne oraz mniej znany podział Kłósaka na teorie nauk przyrodniczych empiriologiczne i ontologizujące ${ }^{8}$. Wydaje się, że Bugajak utożsamia te dwa podziały, w szczególności uznając, że przyjęcie koncepcji empiriologicznej nauk przyrodniczych wymusza opowiedzenie się za antyrealizmem w sporze o status poznawczy teorii naukowych. Prowadzi go to do pesymistycznego wniosku, „że filozof przyrody musi być realistą, jeśli chce mieć nadzieję, że jego dociekania osiągną swój cel, jakim jest zbudowanie ontologii świata materialnego. Jednocześnie być nim nie może, jeśli chce pozostać filozofem przyrody, uznając, że ta dyscyplina ma w ogóle rację bytu wobec rozwoju nauk przyrodniczych" fikacje są niezależne, gdyż opierają się na innych kryteriach. Choć empiriologiczna teoria nauk przyrodniczych może prowadzić do antyrealizmu, to opowiadając się za tą teorią, również można przyjąć realistyczną interpretację nauk przyrodniczych. Brak dostrzeżenia przez Bugajaka możliwości interpretowania teorii naukowych realistycznie mimo przyjęcia teorii empirologicznej (wydaje się, że sam Kłósak był realistą i przypisywał wynikom nauk przyrodniczych prawdziwość), osłabia skądinąd interesujące spostrzeżenia na temat relacji między filozofią a naukami przyrodniczymi. Bugajak zresztą w swoich dociekaniach filozoficznych korzysta z wyników nauk przyrodniczych, interpretując je w duchu realizmu.

W pracach Bugajaka pojawia się też problem celu nauki. Zwraca m.in. uwagę na to, że opowiedzenie się za jednym ze znanych od starożytności ideałów nauki: „wiedzieć, aby wiedzieć” i „wiedzieć,

8 Na temat teorii empiriologicznej i ontologizującej nauk przyrodniczych zob.: K. Kłósak, Z teorii i metodologii filozofii przyrody, dz. cyt., 13-41.

9 G. Bugajak, Filozofia przyrody a spór o status poznawczy teorii naukowych: Czy filozof przyrody może być realista??, w: Filozoficzne i naukowo-przyrodnicze elementy obrazu świata, t. 7, dz. cyt., 89. 
aby używać" wpływa w istotny sposób na rozwiązywanie innych problemów metafilozoficznych, w szczególności pojawiających się przy wykorzystywaniu wyników nauk przyrodniczych w refleksji filozoficznej ${ }^{10}$.

Postulat, by w filozofii korzystać z wyników nauk przyrodniczych, prowadzi Bugajaka do zauważenia, że w filozofii przyrody konieczne jest posługiwanie się narzędziami wypracowanymi przez filozofię nauki. W tym obszarze też szuka propozycji, które pozwalałyby osłabić jego radykalne stanowisko. Znajduje ją w Quine’owskim pojęciu „ontologii postulowanej”"11. Wydaje się, że Bugajak widzi sens uprawiania filozofii przyrody w jej poszukiwaniach podstawowych kategorii ontycznych rzeczywistości. Pomocne w tym przedsięwzięciu są teorie przyrodnicze, z których można niejako „wydobyć” implikowaną przez nie ontologię. Bugajak zdaje sobie sprawę z niejasności pojęcia ontologii postulowanej, toteż próbuje doprecyzować jego treść ${ }^{12}$. Zarazem dostrzega trudności z jednoznaczną rekonstrukcją ontologii teorii przyrodniczej, wynikające z tez o niedookreśloności i o niewspółmierności teorii. Prowadzi go to wniosku, że „konstruowanie ontologii przy wykorzystaniu dokonań nauk przyrodniczych musi się opierać na jakichś przedzałożeniach filozoficznych, które tę niejednoznaczność wyeliminują"13.

Bugajak porusza też inne problemy z zakresu filozofii nauki przy analizie problemów z zakresu filozofii przyrody. Jest mu to potrzebne, by wykorzystać wyniki nauk przyrodniczych, zarazem uzyskuje interesujące wnioski o charakterze metodologiczno-epistemologicznym.

10 Tenże, Początek świata w nauce i religii. W poszukiwaniu możliwości syntezy, Studia Philosophiae Christianae 32(1996)2, 142-143.

11 Zob. np. Tenże, Philosophy of Nature, Realism, and the Postulated Ontology of Scientific Theories, w: Philosophy of Nature Today, red. A. Świeżyński, Wydawnictwo UKSW, Warszawa 2009, 69.

12 Zob. G. Bugajak, Kilka uwag o „postulowanej ontologii” teorii naukowych, Studia Philosophiae Christianae 40(2004)2, 315-322.

13 Tamże, 321. 
Przy rozwiązywaniu problemów dotyczących przestrzeni i czasu naturalne jest posłużenie się wynikami uzyskanymi w geometrii. Prowadzi to do pytania o geometrię przestrzeni wszechświata. Przy rozstrzyganiu tej kwestii Bugajak wskazuje na wnioski o charakterze ogólniejszym, dotyczące kryteriów uznawalności teorii naukowych, czy problemów z experimentum crucis, gdyż wyniki eksperymentów ze względu na skończoną dokładność pomiarów nie mogą dać jednoznacznego rozstrzygnięcia, która $\mathrm{z}$ teorii jest bliższa rzeczywistości ${ }^{14}$. Co więcej, Bugajak dochodzi do ważnego wniosku, że ponieważ „owa niemożność dokonywania pomiarów nieskończenie dokładnych jest fundamentalna, cecha ta jest w pewnej mierze cechą samego świata materialnego. Jest więc nie tylko ograniczeniem poznawczym, ale należy do struktury ontycznej świata" 15 .

Interesujące są też analizy metodologiczno-epistemologiczne czynione przez Bugajaka niejako przy okazji prezentacji filozoficznych aspektów szczególnej teorii względności, a związane $\mathrm{z}$ badaniami nad naturą przestrzeni i czasu. Zagadnienia dotyczące filozoficznych interpretacji transformacji Lorentza, dylatacji czasu, skrócenia długości ciała w ruchu Bugajak rozpatruje w kontekście sporu realizmu $\mathrm{z}$ antyrealizmem w filozofii nauki. Pojawia się też w jego rozważaniach kwestia operacjonizmu oraz pytanie o realność efektów relatywistycznych. W tym kontekście zadaje pytanie: „czy operacjonizm stawia właściwe wymagania definicjom naukowym, a zwłaszcza czy wszystkie definicje muszą mieć charakter operacyjny"16. Wskazywane przez filozofów nauki problemy dotyczące interpretacji teorii przyrodniczych ukazują problem wykorzystywania wyników nauk przyrodniczych w filozofii w innym jeszcze świetle, a mianowicie zasadnie można postawić pytanie: „czy operacyjnie zdefiniowane pojęcia czasu i przestrzeni wskazują

14 G. Bugajak, J. Kukowski, A. Latawiec, A. Lemańska, D. Ługowska, A. Świeżyński, Tajemnice natury. Zarys filozofii przyrody, Wydawnictwo Naukowe UKSW, Warszawa 20192, 66-67.

15 Tamże, 68.

16 Tamże, 98. 
na tę samą rzeczywistość, nad której charakterem zastanawiali się filozofowie od starożytności"17. Zawarta w tym pytaniu wątpliwość może stawiać pod znakiem zapytania sensowność odwoływania się do wyników nauk przyrodniczych w filozofii.

Badania z zakresu problematyki dialogu nauki i religii Bugajak również zaczyna od porządkowania zagadnień metateoretycznych. Ważne $z$ tego punktu widzenia są dokonane przez niego uściślenia jednego z pojęć istotnych w tych dyskusjach, a mianowicie „naturalizmu”. Próbuje przede wszystkim wprowadzić pewien ład w zamęt pojęciowy związany z używaniem tego terminu w różnych znaczeniach. Pokazuje też, które z typów naturalizmu sprzyjają dialogowi nauka - religia, a które z kolei stanowią założenia ontologiczne bądź epistemologiczne, nie mające wiele wspólnego z praktyką badawczą przyrodników. Uporządkowanie używanej terminologii jest ważne, gdyż wielu autorów, którzy uważają, że między naukami przyrodniczymi a religią nie może istnieć żadne porozumienie, jako argument za takim stanowiskiem podaje naturalizm nauk przyrodniczych.

Bugajak wyróżnia cztery typy naturalizmu: „filozoficzny”, semantyczny, metodologiczny i ontologiczny. Jedną z form naturalizmu „filozoficznego” jest tzw. „naturalizm naukowy”, który odmawia autonomii badaniom filozoficznym. Natomiast umiarkowany naturalizm naukowy, choć uznaje pierwszeństwo nauki w badaniu świata, to jednak, według Bugajaka, „unika zarówno skrajności polegającej na odmawianiu filozofii wszelkiej autonomii i jakichkolwiek prawdziwie własnych problemów badawczych, jak i skrajności drugiejprowadzenia dociekań filozoficznych w zupełnym oderwaniu od wiedzy, jakiej dostarcza nauka. Łatwo zauważyć, że postrzeganie wzajemnych związków między nauką a filozofią w perspektywie naturalizmu umiarkowanego nie przekreśla sensowności dialogu nauki i religii, a przeciwnie - temu dialogowi sprzyja. Umożliwia w szczególności formułowanie takich propozycji filozoficznych, które

17 Tamże. 
są z osiągnięciami naukowymi zgodne, a jednocześnie mogą mieć również inne, pozanaukowe (w tym teologiczne) źródła"18.

Naturalizm semantyczny określa, które z pojęć naukowych są sensowne, formułuje również zasady redukcji pojęć niereferencyjnych. $\mathrm{Z}$ kolei stanowiska, określane mianem naturalizmu ontologicznego (albo metafizycznego), nie są jednolite. Bugajak wyróżnia wśród nich, proponując własne nazewnictwo, fizykalistyczny redukcjonizm ontologiczny (będący formą monizmu materialistycznego), redukcjonizm przyrodniczy, naturalizm scjentystyczny, naturalizm przyrodniczy. Łączy je to, że zaprzeczają „supranaturalizmowi”, czyli odrzucają istnienie czynników, pozostających poza znanym światem przyrody ${ }^{19}$.

Następnie Bugajak uzasadnia, że rozmaite formy naturalizmu oprócz nazwanego przez niego umiarkowanym naturalizmem naukowym, który charakteryzuje metody nauk przyrodniczych, są założeniami ontologicznymi bądź epistemologicznymi, określającymi z góry relacje między rzeczywistością przyrodniczą a rzeczywistością transcendentną w stosunku do niej20. Bugajak pokazuje też, które z typów naturalizmu sprzyjają dialogowi nauka - religia. Sam poszerza koncepcję pluralizmu konceptualistycznego Hilarego Putnama tak, by można było wykorzystać ją do uzasadnienia, że dialog nauki przyrodnicze - teologia jest możliwy. Próbuje też pokazać, że „nauki przyrodnicze i teologia, szanując wzajemną odrębność, mogą dostarczać komplementarnych elementów wiedzy o świecie, dzięki czemu nasze rozumienie rzeczywistości - w ramach próby filozoficznych syntez - może stać się pełniejsze"21.

18 G. Bugajak, Problem naturalizmu w dialogu nauki i religii, w: Filozofia przyrody, red. S. Janeczek, A. Starościc, D. Dąbek, J. Herda, Wydawnictwo KUL, Lublin 2013, 305.

19 Tamże, 312-317.

20 Tamże, 301-320. Zob. Tenże, Naturalizm nauki a działanie Boga w świecie, w: Teologia nauki, red. J. Mączka, P. Urbańczyk, Copernicus Center Press, Kraków 2015, 145-172.

21 G. Bugajak, Problem naturalizmu w dialogu nauki i religii, w: Globalizácia ako platforma prieniku prírodných a humanitných vied. Nové formy komunikácie, red. J. Tiňo, Ústredie Slovenskej Krestanskej Inteligencie, Bratislava 2009, 44. 
W kontekście relacji nauka - religia Bugajak postrzega filozofię jako konieczny pośrednik w dialogu między naukami przyrodniczymi i teologią. Podkreśla, że taki dialog jest możliwy, co więcej, nauki przyrodnicze i teologia są równorzędnymi partnerami tego dialogu. Filozofia przyrody korzystająca $z$ wyników nauk przyrodniczych i próbująca stworzyć koncepcję rzeczywistości przyrodniczej pomaga połączyć ze sobą w jedną spójną całość elementy pochodzące i z nauki, i z religii 22 .

Bugajak broni filozofii przed formułowanymi niekiedy zarzutami, że idee filozoficzne i teologiczne są dowolne $\mathrm{i}, \mathrm{w}$ przeciwieństwie do wiedzy naukowej, pozbawione ścisłości. Pokazuje, że „jeśli dociekania podejmowane $\mathrm{w}$ ramach filozofii respektują określone reguły metodologiczne, tak uprawiana filozofia zasługuje w pełni na miano nauki (...), pojętej jako intersubiektywne badanie rzeczywistości, w którym ścisłość i jednoznaczność rozumowań są warunkiem sine qua non sensowności badawczych wysiłków. Jeśli więc filozofia jest racjonalną działalnością naukową, wiodącą do prawdziwego poznania świata, to ramy flozoficznego obrazu świata są wyznaczone kryteriami racjonalności i prawdy, a tym samym dalekie od quasi-filozoficznych luźnych dywagacji”23.

22 „Powyższe rozważania prowadzą do wniosku, że w przypadku konkretnych tez naukowych i teologicznych - jak na przykład w odniesieniu do rzekomego konfliktu między teorią ewolucji a przekonaniem o stworzeniu świata i człowieka przez Boga - można podjąć próbę odczytania owej »postulowanej ontologii«, jaka kryje się w danych teoriach, i w ten sposób stworzyć spójny, filozoficzny obraz tego fragmentu rzeczywistości, którego obie teorie dotyczą. Tworzenie takiego obrazu byłoby zadaniem filozofii, tym bardziej, że wobec ontologicznej niedookreśloności wyjściowych teorii, odczytanie sugerowanej w nich ontologii jest kwestią jakiejś ich filozoficznej interpretacji. Interpretacja taka nie może być zupełnie dowolna - jej ramy wyznaczone są przecież przez kształt analizowanych teorii. Jednocześnie jednak, odpowiednie dobranie filozoficznych narzędzi interpretacyjnych może prowadzić do »uzgodnienia « obu teorii właśnie na płaszczyźnie filozofii” (G. Bugajak, „Rozum a wiara” - problem separacji dyscyplin, Studia Philosophiae Christianae 43(2007)2, 147-148).

23 G. Bugajak, A. Latawiec, Nauka, filozofia i religia a obraz świata, w: Filozoficzne i naukowo-przyrodnicze elementy obrazu świata, t. 2, red. A. Latawiec, K. Kloskowski, G. Bugajak, Wydawnictwo UKSW, Warszawa 2000, 200. 
Interesujące są również analizy Bugajaka dotyczące lęków, które niekiedy wywołują nowe odkrycia naukowe, jak tzw. „syndrom Frankensteina” czy wizje "globalnej katastrofy” spowodowanej eksperymentami w fizyce wysokich energii. Jednocześnie usiłuje uzasadnić, że nie istnieją racjonalne powody do obaw przed naukąa ${ }^{24}$. Paradoksalnie, Bugajak zauważa, że człowiek w gruncie rzeczy w porównaniu z siłami przyrody jest „bezradnym dzieckiem”, a ludzkie „działania, łącznie z tym wszystkim, co postęp naukowy może przynieść światu, są jedynie słabym odbiciem, cieniem działań przyrody. Odpowiedź na pytanie o to, czy postęp naukowy może być niebezpieczny jest w tym świetle oczywista”25. Co więcej, „całkowicie racjonalne jest przekonanie, że siły natury są daleko potężniejsze od ludzkich możliwości, a czas, jakim przyroda dysponowała na przeprowadzenie swych »eksperymentów«, jest nieporównywalnie dłuższy od historii ludzkiej nauki i techniki”26.

\section{WĘZłOWE PROBLEMY FILOZOFII PRZYRODY}

Głównymi zagadnieniami z zakresu filozofii przyrody rozpatrywanymi przez Bugajaka były: problemy związane z początkiem wszechświata, doprecyzowanie pojęcia materii oraz analizy dotyczące zdarzeń przypadkowych w przyrodzie.

Problematyka dotycząca początków wszechświata była podjęta przez Bugajaka w jego rozprawie doktorskiej w kontekście analiz modeli kosmologicznych, w których pojawia się szczególny stan

24 G. Bugajak, Lęk przed nauką. Czy postęp naukowy może być niebezpieczny?, w: Bezpieczeństwo człowieka wobec współczesnych i przyszłych wyzwań. Monografia $\mathrm{nr}$ 1, red. J. Dębowski, E. Jarmoch, A.W. Świderski, Wydawnictwo Akademii Podlaskiej, Siedlce 2005; por. Tenże, Fears of Science. Nature and Human Actions, w: Knowledge and Values, red. A. Świeżyński, Wydawnictwo UKSW, Warszawa 2011.

25 G. Bugajak, Lęk przed nauką. Czy postęp naukowy może być niebezpieczny?, dz. cyt., 40. 26 Tamże. 
wszechświata, jakim jest tzw. Wielki Wybuch ${ }^{27}$. Dostrzegając wielość interpretacji tego szczególnego stanu wszechświata, Bugajak próbuje wydobyć leżące u ich podstaw założenia, często nieformułowane explicite $^{28}$. Koncentruje się na jednym z najistotniejszych filozoficznych problemów, który pojawia się przy analizie modeli kosmologicznych, a mianowicie na kwestii przyczyny wszechświata. Bugajak dochodzi do wniosku, że pojęcie przyczynowości z płaszczyzny nauk przyrodniczych jest niewystarczające, by próbować określać przyczynę Wielkiego Wybuchu. Konieczne jest tu przejście na płaszczyznę filozoficzną. Dopiero na niej można wypracować „definicję zaistnienia, która abstrahowałaby od odniesień czasowych, bądź opierała się na zasadnie sformułowanej koncepcji czasu, wolnej od ograniczeń związanych ze sposobem, w jaki czas rozumie się we współczesnej fizyce" 29 oraz posłużyć się przy wyciąganiu wniosków filozoficzną zasadą przyczynowości ${ }^{30}$.

Te analizy Bugajak kontynuował w następnych pracach. Zwracał $\mathrm{w}$ nich uwagę na pozanaukowe (filozoficzne a także światopoglądowe) czynniki, które mają istotne znaczenie zarówno przy wyborze założeń, na jakich opiera się konstrukcja modeli kosmologicznych, jak i przy ich interpretacjach ${ }^{31}$. W szczególności niektórzy z kosmologów stwierdzają (zwłaszcza w popularno-naukowych opracowaniach), że wszechświat mógł samoistnie wyłonić się z nicości. Bugajak pokazuje, że metafizyczną kategorią „nicości” nie można posłużyć się do interpretacji tzw. fluktuacji próżni kwantowej. Nie można też odnosić kategorii przypadku z porządku ontycznego do interpretacji zjawisk

27 Tenże, Epistemologiczny status koncepcji Wielkiego Wybuchu i jej filozoficzne implikacje, w: Z zagadnień filozofii przyrodoznawstwa i filozofii przyrody, t. 17, red. A. Lemańska, M. Lubański, Wydawnictwo UKSW, Warszawa 2004, 15-112.

28 Tamże, 16.

29 Tamże, 97.

30 Tamże.

31 Tenże, Non-scientific Sources of the Big Bang Model and its Interpretations, w: Studies in Science and Theology, vol. 7, red. N.H. Gregersen, U. Görman, W.B. Drees, Aarhus 2000, 151-159. 
opisywanych w teoriach indeterministycznych. Opis ten bowiem należy do porządku epistemologicznego ${ }^{32}$.

Następnym analizowanym przez Bugajaka zagadnieniem $\mathrm{z}$ zakresu filozofii przyrody jest problem materialności przyrody i wiążące się z nim kwestie dotyczące czasu, przestrzeni oraz jakości. Ten problem Bugajak ściśle łączy z kwestią statusu filozofii przyrody. Skoro bowiem jej przedmiotem jest „świat materialny”, to utworzenie adekwatnego pojęcia materii wydaje się konieczne, by jasno sprecyzować, czym zajmuje się filozofia przyrody ${ }^{33}$. Bugajak problem materii ukazuje zarówno w perspektywie historycznej, jak i wykorzystując wyniki nauk przyrodniczych. Przede wszystkim dokonuje interesujących podziałów koncepcji na temat materii. Dzieli je na substratowe, w których materia jest traktowana jako „tworzywo świata", i atrybutywne, w których materia jest określana przez wskazanie charakterystycznych cech obiektów materialnych. Następnie stwierdza, że koncepcje substratowe można rozumieć bądź fizykalnie, bądź metafizycznie. W tym pierwszym rozumieniu materia daje się poznać zmysłowo, w drugim - wyłącznie na drodze analiz intelektualnych ${ }^{34}$. We współczesnych naukach przyrodniczych, zwłaszcza w fizyce, można dopatrzeć się fizykalnego rozumienia materii. Bugajak zarazem zwraca uwagę na to, że z fizyki współczesnej zniknęła kategoria materii. Świat przyrody na najbardziej elementarnym, podstawowym poziomie jawi się jako świat pól fizycznych, energii, cząstek elementarnych, fal, cząstek wirtualnych, nie ma tu miejsca

32 Tenże, Próżnia - pustka - nicość. Czy wszechświat jest fluktuacją próżni?, w: Człowiek i pustka, red. Z. Hull, W. Tulibacki, Olsztyńska Szkoła Wyższa, Olsztyn 2000, 92-100; zob. też recenzje książek: G. Bugajak, J. Gribbin, In Search of the Big Bang. The Life and Death of the Universe, London 1998, Studia Philosophiae Christianae 35(1999)1, 319-324; Tenże, Roger G. Newton, Thinking about Physics, Princeton UP, Princeton, New Jersey 2000, Studia Philosophiae Christianae 38(2002)2, 175-180.

33 G. Bugajak, Materia, w: Encyklopedia Filozofii Przyrody, red. Z. Roskal, Wydawnictwo KUL, Lublin 2016, 197.

34 Tamże, 199. 
na żaden substrat fizyczny ${ }^{35}$. Z kolei metafizyczne rozumienie materii jest charakterystyczne dla niektórych nurtów filozoficznych. Bugajak omawia pojęcie materii pierwszej, występujące w filozofii arystotelesowsko-tomistycznej. Wskazuje jednak, że to rozumienie materii od starożytności budziło kontrowersje, a współcześnie zdaje się dla filozofii przyrody tracić znaczenie ${ }^{36}$.

$\mathrm{Z}$ kolei, omawiając koncepcje atrybutywne materii, Bugajak wnikliwie analizuje poszczególne cechy przypisywane materii, jak: rozciągłość, bezwładność, przestrzenność, czasowość, podleganie prawidłowościom, zmienność, poznawalność zmysłowa. Dochodzi jednak do wniosku, że żadna $\mathrm{z}$ nich nie jest - w świetle współczesnej wiedzy przyrodniczej - bezdyskusyjna. Na przykład jedna z istotnych własności bytów materialnych, jaką w filozofii klasycznej jest rozciągłość, staje pod znakiem zapytania w świetle cech takich obiektów fizycznych, jak elektrony czy kwarki, a posiadanie masy - wobec własności niektórych bozonów pośredniczących w oddziaływaniach fizycznych ${ }^{37}$.

Dostrzegając problemy z przypisywaniem rzeczom materialnym właściwości, Bugajak zwraca uwagę na szczególną ich cechę, jaką jest obserwowalność. W obiektywnym rozumieniu tej cechy, czyli takim, jakie uniezależnia ją od istnienia i zdolności obserwatorów, wyróżnia jej trzy typy: obserwowalność bezpośrednią, pośrednią $i$ teoretyczną ${ }^{38}$. Bugajak zauważa zarazem, że „kwestia obserwowalności wiąże się przy tym ściśle $\mathrm{z}$ zagadnieniem istnienia obiektów teoretycznych przyrodoznawstwa, zwłaszcza fizyki. Relację między

35 Tamże, 224.

36 „Pojęcie materii pierwszej, jakie występuje w teorii hylemorfizmu, jest bez znaczenia dla współczesnych refleksji nad tym, czym jest materia. Właściwym przedmiotem współczesnej filozofii przyrody jest materia rozumiana fizykalnie, »materia druga«, pojęta przy tym niekoniecznie jako substrat, »materiał « rzeczy, którego istnienie bywa podawane w wątpliwość (...), ale jako abstrakt - pojęcie swym zakresem obejmujące wszystkie rzeczy materialne, a w swej treści zdające sprawę z istotnych cech tych rzeczy" (tamże, 205).

37 Tamże, 215-216.

38 Tamże, 222. 
materialnością a obserwowalnością można bowiem traktować z jednej strony jako problem konceptualny - wówczas obserwowalność jest jednym z kryteriów zaliczania czegoś do zbioru obiektów materialnych, a z drugiej - jako problem faktualny, gdy obserwowalność traktuje się jako dowód istnienia"39.

Bugajak dochodzi do wniosku, że choć pojęcie materii jest jednym $\mathrm{z}$ centralnych pojęć filozofii przyrody, to jego definicja napotyka na istotne trudności. To sprawia, że każde określenie materii ma charakter hipotetyczny. Toteż, według niego, również istnienie materii jest jedynie hipotezą filozoficzną. Tak o tym pisze: „Pojęcie materii jest jednym $z$ centralnych pojęć filozofii przyrody, ponieważ wchodzi $\mathrm{w}$ definicję tej dyscypliny, a z uchwyconych w nim wspólnych, istotnych cech obiektów materialnych wynika duża część jej problematyki: kwestia czasu i przestrzeni, pytanie o zmianę, dynamizm rzeczywistości, problem przyczynowości i determinizmu czy szerzej - prawidłowości przyrodniczych, wreszcie zagadnienie racjonalności świata jako pochodna przekonania o podleganiu poznawalnym prawom. Jednakże trudności dotyczące zarówno każdej ze wskazanych cech z osobna, jak i generalnie - z samym założeniem, że próba uchwycenia takich cech jest właściwym rozwiązaniem problemu definicji materii sprawiają, że określenie takie ma charakter hipotetyczny. Stąd zaś już tylko krok do stwierdzenia, że samo istnienie materii jest jedynie hipotezą filozoficzną" 40 .

Niektóre $\mathrm{z}$ wymienionych cech materii stały się przedmiotem dalszych analiz Bugajaka. W szczególności stwierdza, że klasyczny podział własności na jakościowe i ilościowe jest nie do utrzymania w świetle wyników nauk przyrodniczych ${ }^{41}$.

Czas i przestrzeń jako dwa istotne pojęcia filozofii przyrody $\mathrm{Bu}-$ gajak analizuje, posługując się wynikami uzyskanymi w geometrii

39 Tamże, 223.

40 Tamże, 224-225.

41 G. Bugajak, i inni, Tajemnice Natury, dz. cyt., 47-49. 
(przestrzenie nieeuklidesowe), fizyce (klasyczna mechanika, szczególna teoria względności), a także teorii ewolucji. W szczególności zauważa, że koncepcja czasu i przestrzeni Kanta, wbrew obiegowym interpretacjom, nie uzyskuje uzasadnienia w ewolucjonizmie, gdyż nawet jeżeli „przestrzeń jest wrodzoną kategorią poznawczą, to w myśl ewolucyjnej teorii poznania kategoria ta pojawiła się w ludzkich władzach poznawczych dlatego, że w świecie istnieje coś, co jej odpowiada"42.

Interesujące są analizy Bugajaka, dotyczące tzw. termodynamicznej strzałki czasu. W codziennym doświadczeniu bez żadnych wahań odróżniamy przeszłość od przyszłości. Jednak próby zobiektywizowania tego doświadczenia, czyli znalezienia takich zjawisk fizycznych, w których złamana byłaby symetria czasu, napotyka na trudności. Bugajak pokazuje, że odwołanie się do termodynamiki jest problematyczne $z$ następujących powodów. Przede wszystkim II zasada termodynamiki, która jest podstawą termodynamicznego rozwiązania problemu strzałki, odnosi się do układów zamkniętych. Tego pojęcia jednak nie sposób poprawnie odnieść do Wszechświata. Zasada ta ma też charakter fenomenologiczny oraz statystyczny, co oznacza między innymi, że istnieje niezerowe prawdopodobieństwo jej złamania ${ }^{43}$.

Następne pojęcie, analizowane przez Bugajaka, to pojęcie przypadku i wiążące się z tym problemy, dotyczące determinizmu i przyczynowości. Szczególnie ważna jest próba klasyfikacji rozumienia przypadku odwołująca się do pojęć przyczyny i celu. Przypadek według Bugajaka może być rozumiany jako zdarzenie albo bez przyczyny, albo bez celu. Brak przyczyny można rozpatrywać bądź na płaszczyźnie ontologicznej (brak przyczyny), bądź epistemologicznej (nieznajomość przyczyny). $\mathrm{Na}$ obu tych płaszczyznach przypadek może być absolutny lub względny. $Z$ kolei przypadek rozumiany jako

42 Tamże, 55.

43 Tamże, 78-80. 
brak celu może mieć sens przedmiotowy (chodzi tu o „naturalne nakierowanie" związane z prawami przyrody) lub podmiotowy (cel jest ustalany przez świadomy podmiot). W obu tych sytuacjach można rozpatrywać przypadek na płaszczyźnie ontologicznej bądź epistemologicznej. I, podobnie jak w sytuacji przypadku rozumianego jako brak przyczyny, przypadek w każdej z tych czterech perspektyw może mieć charakter absolutny bądź względny. Bugajak uzyskuje zatem dwanaście różnych sposobów rozumienia pojęcia przypadku ${ }^{44}$, które, jak się wydaje, wyczerpują podstawowe sensy nadawane temu pojęciu.

Następnie Bugajak próbuje, odwołując się do swojej klasyfikacji zdarzeń przypadkowych, stwierdzić, czy poszczególne zdarzenia z różnych obszarów rzeczywistości przyrodniczej mogą być potraktowane jako przypadkowe w jednym z wymienionych sensów. Przede wszystkim Bugajak bada, czy są zdarzenia przypadkowe w znaczeniu absolutnego braku przyczyny w sensie ontologicznym. Często za tego typu zdarzenia uważa się te, które zachodzą na poziomie mikroświata. Bugajak dochodzi jednak do wniosku, że takie traktowanie zdarzeń kwantowych „opiera się na dość silnych (często milczących) założeniach filozoficznych, do których należy między innymi specyficzne i zawężone pojęcie przyczyny"45. Toteż nie jest możliwe stwierdzenie, czy rzeczywiście w przyrodzie zachodzą zdarzenia bez przyczyny. Co więcej, Bugajak zauważa, że indeterminizm mechaniki kwantowej jest uzależniony od interpretacji zasady nieoznaczoności Heisenberga oraz funkcji falowej będącej rozwiązaniem równania Schrödingera. Poza tym nie istnieje bezpośrednie przejście od teorii naukowej, dotyczącej jakiejś sfery zjawisk do twierdzeń o ontycznych własnościach świata. Toteż nawet jeżeli teoria mikroświata jest indeterministyczna, nie musi to oznaczać, że w świecie zachodzą

44 G. Bugajak, Pojęcie przypadku i jego zastosowanie w analizach teorii naukowych, w: Filozofia przyrody współcześnie, red. M. Kuszyk-Bytniewska, A. Łukasik, Wydawnictwo Universitas, Kraków 2010, 235-245.

45 Tamże, 237. 
zdarzenia „absolutnie” przypadkowe ${ }^{46}$. Zatem na poziomie mikroświata mamy raczej do czynienia $\mathrm{z}$ kategorią przypadku jako braku przyczyny w sensie epistemologicznym ${ }^{47}$.

Bugajak analizuje też zagadnienie przypadkowego wyłonienia się Wszechświata z próżni kwantowej. Dochodzi do wniosku, że uznanie, iż Wszechświat powstał przez przypadek z nicości, wymagałoby „przyjęcia dwu dodatkowych założeń. Pierwsze, związane $\mathrm{z}$ interpretacją zasady nieoznaczoności Heisenberga, polegałoby na utożsamieniu przypadkowości z indeterminizmem; drugie - na uznaniu równoważności pojęć próżni i nicości”48.

Bugajak zwraca też uwagę na to, że np. na procesy ewolucyjne można patrzeć jako na wynik działania zbiegających się przyczyn sprawczych. Tego typu zdarzenia można traktować jako przypadkowe w znaczeniu przypadku jako braku przyczyny we względnym sensie ontologicznym ${ }^{49}$. Natomiast takie czynniki ewolucyjne, jak np. mutacje, są przykładem przypadku rozumianego jako przedmiotowy brak celu ${ }^{50}$.

W pracach podejmujących zagadnienia przedmiotowe filozofii przyrody, zwraca szczególną uwagę umiejętne wykorzystywanie przez Bugajaka wyników nauk przyrodniczych, które stają się punktem wyjścia jego analiz w obszarze filozofii przyrody. Dzięki temu wnioski filozoficzne mają solidną podstawę w informacjach dotyczących świata materialnego. Należy podkreślić, że Bugajak, zanim wykorzysta wyniki jakiejś teorii przyrodniczej, dokonuje ich wnikliwej

46 Tenże, Causality and Determinism in Modern Physics, w: Knowledge and Values, dz. cyt., 90.

47 Tenże, Pojęcie przypadku i jego zastosowanie w analizach teorii naukowych, dz. cyt., 238.

48 Tenże, Próżnia - pustka - nicość. Czy wszechświat jest fluktuacją próżni?, dz. cyt., 98. Por. Tenże, Nauka i religia - spotkanie na Początku?, Advances in Clinical and Experimental Medicine 10(2001)2, suppl. 1, 31-34.

49 Tenże, Pojęcie przypadku i jego zastosowanie w analizach teorii naukowych, dz. cyt., 237-238.

50 Tamże, 241. Por. Tenże, Naturalizm nauki a działanie Boga w świecie, dz. cyt., 145-172. 
analizy metodologiczno-epistemologicznej. Próbuje też wydobyć założenia teorii, ukryte przesłanki, metody uzyskiwania wyników, interpretuje też te wyniki w duchu realizmu epistemologicznego.

\section{RELACJE MIĘDZY NAUKĄ A RELIGIĄ}

Ważnym obszarem badań Bugajaka były analizy różnych aspektów relacji między naukami przyrodniczymi a teologią. Jego zainteresowanie tymi zagadnieniami początkowo było konsekwencją rozważań na temat koncepcji Wielkiego Wybuchu i związanego z nią problemu początku Wszechświata. W naturalny sposób w tym kontekście pojawia się bowiem pytanie o przyczynę Wielkiego Wybuchu. Bugajak zauważa, że to pytanie wywołuje dyskusje, w których zajmowane są krańcowo odmienne rozstrzygnięcia: „od kwestionowania jakichkolwiek filozoficznych implikacji Wielkiego Wybuchu, aż po doszukiwanie się w nim potwierdzenia religijnej doktryny o stworzeniu świata" ${ }^{1}$. Bugajak zastanawia się, dlaczego tak się dzieje. Sam zaś dokonuje próby porównania naukowego opisu początku Wszechświata z koncepcją kreacji, mieszczącą się już na płaszczyźnie religijnej i teologicznej52. Dochodzi do wniosku, że nie ma wystarczających podstaw do utożsamiania idei creatio ex nibilo z hipotezami powstania Wszechświata z fluktuacji tzw. kwantowej próżni. Creatio ex nibilo jest bowiem koncepcją teologiczną, która może być różnie interpretowana. Występuje też w niej pojęcie nicości, które ma charakter metafizyczny. Natomiast pojęcie „próżni kwantowej” jest

51 Tenże, Wokół problemu przyczyny Wielkiego Wybuchu, Studia Philosophiae Christianae 31(1995)2, 168.

52 Zob. Tenże, The Beginning of the World in Science and Religion. A Possibility of Synthesis?, w: Studies in Science and Theology, vol. 5: The Interplay Between Scientific and Theological Worldwiews, part I, red. N.H. Gregersen, U. Görman, Ch. Wassermann, Geneva 1999, 151-159. 
pojęciem z obszaru fizyki i ma tu swoje dobrze określone znaczenie. Nie jest zatem nicością w sensie metafizycznym ${ }^{53}$.

Interesujące są też wyniki badań prowadzonych przez Bugajaka wraz Jackiem Tomczykiem w ramach projektu: Current controversies about human origins: Between anthropology and the Bible ${ }^{54}$. Badania $\mathrm{w}$ ramach tego grantu dotyczyły kwestii ściśle związanych $\mathrm{z}$ dialogiem między naukami przyrodniczymi a religią, a mianowicie problemu kontrowersji między ewolucjonizmem a kreacjonizmem w kontekście powstania człowieka. W tych badaniach zastosowano niekonwencjonalne podejście, gdyż przeanalizowano przeprowadzone wśród pracowników naukowych, nauczycieli i studentów ankiety na temat kontrowersji ewolucjonizm - kreacjonizm. $Z$ analizy tych ankiet wyłania się interesujący wniosek, że istnieje zależność między stosunkiem do religii a stanowiskiem zajmowanym w tym sporze. Natomiast mniej znaczące jest wykształcenie oraz wiedza przyrodnicza i religijna ankietowanych ${ }^{55}$. Choć badania ankietowe nie są narzędziem badawczym filozofa, to uświadomienie i zidentyfikowanie źródeł kontrowersji ewolucjonizm - kreacjonizm pozwala, już na płaszczyźnie filozoficznej, znaleźć odpowiednie argumenty pozwalające połączyć te dwa stanowiska w jedno. Bugajak i Tomczyk

53 Tenże, Nauka i religia - spotkanie na Początku?, dz. cyt.

54 Na realizację tego projektu został przyznany przez Elon University (USA) i Universitet Interdisciplinaire de Paris (Francja) grant w ramach programu Global Perspectives on Science and Spirituality.

55 Analizie tych ankiet są poświęcone następujące artykuły: G. Bugajak, J. Tomczyk, Wokół ewolucji i kreacji - wstępna analiza ankiet nauczycieli i studentów, Studia Ecologiae et Bioethicae 4(2006), 181-199; G. Bugajak, J. Tomczyk, Kontrowersje wokół powstania człowieka - wstępna analiza ankiet studentów, Studia Ecologiae et Bioethicae 5(2007), 43-59; G. Bugajak, J. Tomczyk, Between Evolution and Creation: A Forgotten Lesson, Omega. Indian Journal of Science and Religion 7(2008)2, 6-21; G. Bugajak, J. Tomczyk, On Evolution and Creation. Problem solved? - The Polish example, Zygon. Journal of Religion and Science 44(2009)4, 859-877. Szczególnym owocem współpracy Bugajaka i Tomczyka jest książka: Między ewolucją a stworzeniem. Materiały dla nauczycieli szkół ponadgimnazjalnych (Warszawa 2010), w której autorzy wykorzystali wyniki swych badań w ramach grantu i swoje nabyte w trakcie jego realizacji doświadczenia. 
analizują historię konfliktu ewolucjonizmu z kreacjonizmem, merytoryczne powody „napięcia” między twierdzeniami teologicznymi a wiedzą naukową odnośnie do powstania i istoty człowieka, rozumienie „duchowego pierwiastka” w człowieku, tezę o wyjątkowości gatunku ludzkiego w świecie przyrody ${ }^{56}$. Rozważają też problem powstania gatunku ludzkiego w kontekście sporu między ewolucjonistami a kreacjonistami oraz kontrowersji między monogenizmem a poligenizmem. Dochodzą do wniosku, że rozstrzygnięcie pierwszej kontrowersji napotyka na przeszkodę w postaci braku jasnego kryterium odróżniania jednego gatunku biologicznego od innego, co sprawia, że samo pojęcie gatunku ma charakter konwencjonalistyczny ${ }^{57}$. $\mathrm{Z}$ kolei ta druga kontrowersja ma szczególne znaczenie dla teologii w związku z nauką o grzechu pierworodnym. Autorzy proponują, by przestrzegać rozdziału między płaszczyzną nauk przyrodniczych, na której rozpatruje się kontrowersję między monocentryzmem a policentryzmem, a płaszczyzną teologii, na której monogenizm jest związany z nauką o grzechu pierworodnym ${ }^{58}$.

Bugajak podejmuje też problem działania Boga w świecie przyrody. Spośród rozmaitych stanowisk w tej kwestii wybiera panenteizm jako „sposób łącznego wyrażenia chrześcijańskiej prawdy o Bogu, który jest jednocześnie całkowicie odrębny od świata i całkowicie w nim

56 G. Bugajak, J. Tomczyk, Human Origins: Continuous Evolution Versus Punctual Creation, in: Global Perspectives on Science and Spirituality, red. P. Das, Templeton Press, West Conshohocken 2009, 143-164. Zob. także G. Bugajak, „Adamie, gdzie jesteś?” Kilka uwag o istocie człowieczeństwa, w: Teologiczna, filozoficzna i naukowa wizja człowieka, red. P. Moskal, Wydawnictwo KUL, Lublin 2018, 83-98.

57 G. Bugajak, J. Tomczyk, Human Origins: Continuous Evolution Versus Punctual Creation, dz. cyt., 146-147.

58 G. Bugajak, J. Tomczyk, Between Evolution and Creation: A Forgotten Lesson, dz. cyt., 17-18. Por. G. Bugajak, J. Tomczyk, Creation and evolution: Towards a coherent picture of world and man, w: God and nature. Selected Issues in the Philosophy and Theology of Nature, red. A. Świeżyński, Wydawnictwo UKSW, Warszawa 2014, 71-93. 
obecny"59. To rozwiązanie pozwala uzgodnić istotne prawdy wiary $z$ danymi dostarczanymi przez nauki przyrodnicze, a w konsekwencji uniknąć kontrowersji i skrajności zarówno ewolucjonizmu, jak i kreacjonizmu. Bugajak zarazem stawia tezę o „niedookreśloności celu stworzenia”. W odniesieniu do powstania człowieka, rozumianego jako istota wezwana przez Boga do nawiązania z Nim szczególnej relacji, teza ta oznacza, $\dot{z} e$ „wystarczy by istota taka miała dostatecznie rozwinięte władze poznawcze, rozum w minimalnym stopniu zdolny do choćby intuicyjnego pojęcia transcendencji i samoświadomość. Nie ma żadnego powodu, by sądzić, że cechy takie może mieć tylko jeden, z góry i w szczegółach "zaplanowany« konkretny gatunek biologiczny. Nawet więc jeśli ewolucja jest przypadkowa w tym sensie, że nie można jej przypisać żadnego ukierunkowania, to jeśli tylko zachodzi, daje szanse na powstanie istoty, którą Stwórca może zaprosić do dialogu z sobą, niezależnie od szczegółów jej naturalnego wyposażenia. Zatem jeśli człowiek jest celem stworzenia (człowiek, a niekoniecznie Homo sapiens), to cel ten może się realizować nie tylko na różnych drogach, ale i przybrać kształt - w szerokich granicach fizycznie dowolny"60.

Problemy, dotyczące początku Wszechświata oraz kontrowersji między ewolucjonizmem a kreacjonizmem, prowadzą do podjęcia przez Bugajaka znacznie bardziej fundamentalnej kwestii, a mianowicie istoty relacji między nauką a wiarą. Warto zwrócić uwagę na to, że ten problem Bugajak umieszcza w kontekście historycznym. W szczególności odnosi się do „sprawy Galileusza”, która jest najczęściej przywoływanym przykładem konfliktu między nauką a religią, i wskazuje na jej złożoność. Według niego nieuwzględnienie całego kontekstu historyczno-psychologiczno-socjologicznego wypacza dzisiejsze interpretacje tego wydarzenia, jest też przestrogą dla obecnie

59 G. Bugajak, Czy procesy naturalne mogą realizować cele nadnaturalne?, Roczniki Filozoficzne 68(2020)4, 103.

60 G. Bugajak, Naturalizm nauki a działanie Boga w świecie, dz. cyt., 171-172. 
toczonych dyskusji ${ }^{61}$. Bugajak uważa, że był to raczej konflikt Galileusza z Kościołem jego czasów niż przykład sprzeczności ówczesnej nauki i teologii. Aby to wykazać, Bugajak wymienia rodzaje błędów, jakie wówczas popełniły obie strony sporu. Do błędów tych należy merytoryczny błąd naukowy, który popełnił sam Galileusz, twierdząc niezgodnie z faktami, że dysponuje dowodami heliocentryzmu. Podobnie metodologiczny błąd naukowy również obciąża Galileusza, traktującego heliocentryzm nie tylko jako wygodne narzędzie obliczeń i przewidywań (tak heliocentryzm był traktowany przez wielu astronomów tamtego czasu), lecz jako prawdę o świecie ${ }^{62}$. Dwa następne typy błędów obciążają już teologów. Są nimi merytoryczny błąd teologiczny, polegający na błędnej identyfikacji przedmiotu Objawienia oraz metodologiczny błąd teologiczny dotyczący kwestii interpretacji Biblii. Ostatnim zidentyfikowanym przez Bugajaka błędem jest błąd „w badaniach interdyscyplinarnych”, polegający na przekraczaniu granic kompetencji poszczególnych dziedzin wiedzy. Bugajak posługując się swoją 'typologią błędów', wykazuje, że we współczesnych sporach wokół niektórych nauk stosowanych (np. biotechnologii) żaden $\mathrm{z}$ tego rodzaju błędów nie jest popełniany, a więc, że sprawa Galileusza nie dostarcza rzetelnych argumentów w tych dyskusjach ${ }^{63}$.

Bugajak nie poprzestaje na rozwiązywaniu szczegółowych problemów, dotyczących relacji między naukami przyrodniczymi a teologią czy religią. Dostrzegając bowiem trudności metateoretyczne dialogu nauki i religii, próbuje uporządkować pole badawcze z tym związane.

61 Tenże, Theology and Genetic Engineering: New incarnation of the old conflict?, w: Studies in Science and Theology, vol. 9, red. U. Görman, W.B. Drees, H. Meisinger, Lund 2004, 127-143.

62 Jest interesujące, że dokumenty kościelne zezwalały na przyjmowanie heliocentryzmu ex suppositione i doceniały jego walory praktyczne, w czym można się doszukać zrębów stanowiska nazywanego dzisiaj instrumentalizmem w filozofii nauki.

63 G. Bugajak, Theology and Genetic Engineering: New incarnation of the old conflict?, dz. cyt., 138-139. 
Broni przede wszystkim tezy o odrębności płaszczyzn poznawczych nauk przyrodniczych i teologii, podważanej zarówno przez zwolenników poglądu o nieusuwalnym konflikcie nauki i religii, jak i przez zwolenników integracji tych dwóch dziedzin. Podaje szereg argumentów za tą tezą, a także przykłady rozwiązań kilku problemów ${ }^{64}$. Uważa, że wbrew krytykom teza ta jest dobrze uzasadniona i jest „adekwatnym narzędziem opisu relacji nauki i religii”"65.

Broniąc tezy o rozdzielności płaszczyzn poznawczych, Bugajak jednocześnie podkreśla, że między teologią (religią) a naukami przyrodniczymi nie istnieje nieusuwalny konflikt. Mamy bowiem do czynienia z jedną rzeczywistością, tylko opisywaną różnymi metodami ${ }^{66}$. Odrębność płaszczyzn nauk przyrodniczych i teologii nie przekreśla zatem możliwości syntezy obrazów świata pochodzących z tych dwóch źródeł67. Ta synteza jest możliwa m.in. dzięki swoistemu przekraczaniu granic. Bugajak wskazuje na to, w szczególności

64 Tenże, „Rozum a wiara” - problem separacji dyscyplin, dz. cyt., 132-148.

65 Tenże, Adekwatność tezy o rozdzielności płaszczyzn poznawczych. Głos w imieniu mieszkańców „opancerzonego bunkra”, w: Filozofia - nauka - religia. Księga jubileuszowa dedykowana Profesorowi Kazimierzowi Jodkowskiemu z okazji 40-lecia pracy naukowej, red. P. Bylica, K.J. Kilian, R. Piotrowski, D. Sagan, Oficyna Wydawnicza Uniwersytetu Zielonogórskiego, Zielona Góra 2015, 180. „Teza o rozdzielności płaszczyzn nie podoba się ani przeciwnikom religii - bo odbiera im szansę łatwego »naukowego ataku« na religię, ani jej naukowo uświadomionym wyznawcom - bo zmusza do budowania subtelniejszych narzędzi »dialogu« nauki i religii bez gwarancji łatwego sukcesu. Jej odrzucenie mogłoby - paradoksalnie - zbliżyć oba obozy, oferując im przynajmniej wspólny punkt wyjścia do polemik. Kłopot jednak w tym, że jest to przekonanie słuszne, niezależnie od wysiłków niejednego autora zmierzających do jego zakwestionowania" (tamże, 181).

66 „Dawniejsze przekonanie o nieusuwalnym antagonizmie między tymi dyscyplinami, a co najmniej o ich absolutnej separacji zdaje się ustępować obserwacji, że choć nauka i teologia sytuują się na odrębnych płaszczyznach poznawczych, to przedmiotem ich obu jest po części ten sam: świat, jaki badają nauki przyrodnicze jest tym samym światem, o którym wypowiada się także teologia" (G. Bugajak, Nauka i religia - spotkanie na Początku?, dz. cyt., 31).

67 Tenże, Początek świata w nauce i religii. W poszukiwaniu możliwości syntezy, dz. cyt., 145-147. 
analizując pojęcie postulowanej ontologii ${ }^{68}$ oraz rozszerzając koncepcje pluralizmu konceptualistycznego Hilarego Putnama ${ }^{69}$. Bugajak stwierdza bowiem, że „zrozumienie świata w całej jego złożoności wymaga spojrzenia nań z punktu widzenia wielu dyscyplin, z których każda, badając swój przedmiot $\mathrm{w}$ innym aspekcie, przyczynia się do tworzenia komplementarnego obrazu rzeczywistości. W takiej perspektywie dialog nauki i religii staje się nie tylko możliwy, ale wręcz konieczny, oczywiście nie dla którejkolwiek z tych dyscyplin z osobna - dla jakieś dziedziny przyrodoznawstwa, czy dla teologii samych w sobie - ale właśnie z punktu widzenia potrzeby tworzenia możliwie pełnej wizji świata"70.

Co więcej, Bugajak stwierdza, że Kuhnowska teza o niewspółmierności teorii oraz teza Duhema-Quine’a o niedookreśloności teorii pozwalają przekroczyć rozdzielenie nauki i religii i budować spójny obraz rzeczywistości, „który zawierałby w sobie elementy zarówno wiedzy naukowej, jak i przekonań religijnych (teologicznych)"71. Istotną rolę odgrywałaby w tym filozofia, która staje się w tym przypadku „trzecim partnerem” dialogu i „która pełni tu rolę narzędzia interpretacyjnego i płaszczyzny »spotkania« ontologicznych wniosków, które płyną niezależnie z obu źródeł: naukowego i teologicznego"72.

Możliwą przestrzenią łączenia obrazów świata przyrodniczego i religijnego jest według Bugajaka światopogląd, który tworzą przekonania poszczególnych ludzi i który składa się z niepowiązanych

68 Tenże, Rozum a wiara - rola filozofii, w: Igor Hrušowsky. Osobnost' slovenskiej filozofie, red. Z. Plašienková, E. Laliková, IRIS, Bratislava 2007; wersja poprawiona i rozszerzona: „Rozum a wiara”. Problem separacji dyscyplin, dz. cyt.

69 Tenże, Problem naturalizmu w dialogu nauki i religii, dz. cyt., 37-53. Bugajak tak charakteryzuje stanowisko Putnama: „To pluralistyczne stanowisko zasadza się na odrzuceniu twierdzenia, że jakaś wybrana metoda, czy zbiór metod funkcjonujących w którejś z dyscyplin naukowych jest odpowiednia dla wszystkich naszych celów poznawczych" (tamże, 43).

70 Tamże, 44.

71 G. Bugajak, „Rozum a wiara” - problem separacji dyscyplin, dz. cyt., 145.

72 Tamże, 148. Por. G. Bugajak, Rozum a wiara - rola filozofii, dz. cyt., 355-361. 
elementów. Niemniej światopogląd nie musi być irracjonalny. Budując racjonalny światopogląd, „należy: 1) strzec się przekonania, że cała wartościowa wiedza zamyka się w jednym tylko rodzaju poznania (...);2) nie ulegać złudzeniu, że wszystkie rodzaje poznania mają taką samą wartość (...);3) każdą tezę, czy przekonanie, które przyjmuje się jako element światopoglądu, przyjmować wraz z obiektywną oceną jego wiarygodności"73.

Badania Grzegorza Bugajaka, dotyczące relacji nauki i wiary, są obecnie szczególnie ważne i mogą pomóc przezwyciężyć szereg nieporozumień, które narosły wokół tego problemu. Ujawnia się też w nich umiejętność odwoływania się do różnych dziedzin wiedzy: nauk przyrodniczych (fizyki), teologii i filozofii. Współcześnie dla filozofa zdolność patrzenia na problemy z różnych punktów widzenia jest bardzo cenna, gdyż wiedza o świecie „poszatkowana” na poszczególne dyscypliny naukowe przestaje być przydatna w tworzeniu pewnej całościowej wizji rzeczywistości, co jest jednym z głównych zadań filozofa.

\section{BIBLIOGRAFIA}

Bugajak G. „Rozum a wiara” - problem separacji dyscyplin, Studia Philosophiae Christianae 43(2007)2, 132-148.

Bugajak G., (rec.) J. Gribbin, In Search of the Big Bang. The Life and Death of the Universe, London 1998, Studia Philosophiae Christianae 35(1999)1, 319-324.

Bugajak G., (rec.) Roger G. Newton, Thinking about Physics, Princeton UP, Princeton, New Jersey 2000, Studia Philosophiae Christianae 38(2002)2, 175-180.

Bugajak G., „Adamie, gdzie jestes?” Kilka uwag o istocie cztowieczeństwa, w: Teologiczna, filozoficzna i naukowa wizja cztowieka, red. P. Moskal, Wydawnictwo KUL, Lublin 2018, 83-98.

Bugajak G., Adekwatność tezy o rozdzielności ptaszczyzn poznawczych. Gtos wimieniu mieszkańców „opancerzonego bunkra”, w: Filozofia - nauka - religia. Księga jubileuszowa dedykowana Profesorowi Kazimierzowi Jodkowskiemu z okazji 40-lecia

73 Tenże, The Beginning of the World in Science and Religion. A Possibility of Synthesis?, dz. cyt., 40. 
pracy naukowej, red. P. Bylica, K.J. Kilian, R. Piotrowski, D. Sagan, Oficyna Wydawnicza Uniwersytetu Zielonogórskiego, Zielona Góra 2015, 173-190.

Bugajak G., Causality and Determinism in Modern Physics, w: Knowledge and Values, red. A. Świeżyński, Wydawnictwo UKSW, Warszawa 2011, 73-94.

Bugajak G., Czy ludzie wierzacy mogq uznawać teorię ewolucji?, w: Wierzyć i rozumieć, red. G. Dziewulski, M. Marczak, A. Perzyński, J. Wolski, Archidiecezjalne Wydawnictwo Łódzkie, Łódź 2013, 53-56.

Bugajak G., Czy Pan Bóg rzeczywiście stworzyt świat?, w: Wierzyć i rozumieć, red. G. Dziewulski, M. Marczak, A. Perzyński, J. Wolski, Archidiecezjalne Wydawnictwo Łódzkie, Łódź 2013, 45-48.

Bugajak G., Czy procesy naturalne mogq realizowaí cele nadnaturalne?, Roczniki Filozoficzne 68(2020)4, 89-109.

Bugajak G., Epistemologiczny status koncepcji Wielkiego Wybuchu ijej flozoficzne implikacje, w: Z zagadnień filozofii przyrodoznawstwa i flozofi przyrody, t. 17, red. A. Lemańska, M. Lubański, Wydawnictwo UKSW, Warszawa 2004, 15-112. Bugajak G., Fears of Science. Nature and Human Actions, w: Knowledge and Values, red. A. Świeżyński, Wydawnictwo UKSW, Warszawa 2011, 157-170.

Bugajak G., Filozofia przyrody a spór o status poznawczy teorii naukowych: Czy filozof przyrody może być realista?, w: Filozoficzne i naukowo-przyrodnicze elementy obrazu świata, t. 7, red. A. Latawiec, G. Bugajak, Wydawnictwo UKSW, Warszawa 2008, 80-89.

Bugajak G., Kilka uwag o „postulowanej ontologii” teorii naukowych, Studia Philosophiae Christianae 40(2004)2, 315-322.

Bugajak G., Kukowski J., Latawiec A., Lemańska A., Ługowska D., Świeżyński A., Tajemnice natury. Zarys flozofii przyrody, Wydawnictwo Naukowe UKSW, Warszawa $2019^{2}$.

Bugajak G., Latawiec A., Nauka, flozofia i religia a obraz świata, w: Filozoficzne i naukowo-przyrodnicze elementy obrazu świata, t. 2, red. A. Latawiec, K. Kloskowski, G. Bugajak, Wydawnictwo UKSW, Warszawa 2000, 7-12.

Bugajak G., Lękprzed nauką. Czy postęp naukowy może być niebezpieczny?, w: Bezpieczeństwo cztowieka wobec wspótczesnych i przysztych wyzwań. Monografia nr 1, red. J. Dębowski, E. Jarmoch, A.W. Świderski, Wydawnictwo Akademii Podlaskiej, Siedlce 2005, 34-40.

Bugajak G., Materia, w: Encyklopedia Filozofii Przyrody, red. Z. Roskal, Wydawnictwo KUL, Lublin 2016, 195-227.

Bugajak G., Naturalizm nauki a dziatanie Boga w świecie, w: Teologia nauki, red. J. Mączka, P. Urbańczyk, Copernicus Center Press, Kraków 2015, 145-172. 
Bugajak G., Nauka i religia - spotkanie na Poczqtku?, Advances in Clinical and Experimental Medicine 10(2001)2, suppl. 1, 31-34.

Bugajak G., Non-scientific Sources of the Big Bang Model and its Interpretations, w: Studies in Science and Theology, vol. 7, red. N.H. Gregersen, U. Görman, W.B. Drees, Aarhus 2000, 151-159.

Bugajak G., Nowa fizyka, Posłaniec 139(2010)1, 52-53.

Bugajak G., O luksusie filozofowania, Roczniki Filozoficzne 54(2006)1, 342-345. Bugajak G., Philosophy of Nature, Realism, and the Postulated Ontology of Scientific Theories, w: Philosophy of Nature Today, red. A. Świeżyński, Wydawnictwo UKSW, Warszawa 2009, 59-80.

Bugajak G., Początek świata w nauce i religii. W poszukiwaniu możliwości syntezy, Studia Philosophiae Christianae 32(1996)2, 135-147.

Bugajak G., Pojecie przypadku i jego zastosowanie w analizach teorii naukowych, w: Filozofia przyrody wspótcześnie, red. M. Kuszyk-Bytniewska, A. Łukasik, Wydawnictwo Universitas, Kraków 2010, 235-245.

Bugajak G., Problem naturalizmu w dialogu nauki i religii, w: Filozofia przyrody, red. S. Janeczek, A. Starościc, D. Dąbek, J. Herda, Wydawnictwo KUL, Lublin 2013, 301-320.

Bugajak G., Problem naturalizmu w dialogu nauki i religii, w: Globalizácia ako platforma prieniku prírodných a humanitných vied. Novéformy komunikácie, red. J. Tiňo, Ústredie Slovenskej Krestanskej Inteligencie, Bratislava 2009, 37-53.

Bugajak G., Próżnia - pustka - nicość. Czy wszechświat jest fluktuacja próżni?, w: Człowiek i pustka, red. Z. Hull, W. Tulibacki, Olsztyńska Szkoła Wyższa, Olsztyn 2000, 92-100.

Bugajak G., Rozum a wiara - rola flozofii, w: Igor Hrušowsky. Osobnost'slovenskiej filozofie, red. Z. Plašienková, E. Laliková, IRIS, Bratislava 2007, 355-361.

Bugajak G., Skąd wziąt sięcztowiek?, w: Wierzyć i rozumieć, red. G. Dziewulski, M. Marczak, A. Perzyński, J. Wolski, Archidiecezjalne Wydawnictwo Łódzkie, Łódź 2013, 49-52.

Bugajak G., The Beginning of the World in Science and Religion. A Possibility of Synthesis?, w: Studies in Science and Theology, vol. 5: The Interplay Between Scientific and Theological Worldwiews, part I, red. N.H. Gregersen, U. Görman, Ch. Wassermann, Geneva 1999, 151-159.

Bugajak G., Theology and Genetic Engineering: New incarnation of the old conflict?, w: Studies in Science and Theology, vol. 9, red. U. Görman, W.B. Drees, H. Meisinger, Lund 2004, 127-143.

Bugajak G., Tomczyk J., Between Evolution and Creation: A Forgotten Lesson, Omega. Indian Journal of Science and Religion 7(2008)2, 6-21. 
Bugajak G., Tomczyk J., Creation and evolution: Towards a coherent picture of world and man, w: God and nature. Selected Issues in the Philosophy and Theology of Nature, red. A. Świeżyński, Wydawnictwo UKSW, Warszawa 2014, 71-93.

Bugajak G., Tomczyk J., Human Origins: Continuous Evolution Versus Punctual Creation, in: Global Perspectives on Science and Spirituality, red. P. Das, Templeton Press, West Conshohocken 2009, 143-164.

Bugajak G., Tomczyk J., Kontrowersje wokót powstania cztowieka - wstępna analiza ankiet studentórw, Studia Ecologiae et Bioethicae 5(2007), 43-59.

Bugajak G., Tomczyk J., On Evolution and Creation. Problem solved? - The Polish example, Zygon. Journal of Religion and Science 44(2009)4, 859-877.

Bugajak G., TomczykJ., Wokót ewolucji i kreacji-wstępna analiza ankiet nauczycieli i studentów, Studia Ecologiae et Bioethicae 4(2006), 181-199.

Bugajak G., W chwili zero, Posłaniec 139(2010)2, 48-49.

Bugajak G., Wokót problemu przyczyny Wielkiego Wybuchu, Studia Philosophiae Christianae 31(1995)2, 167-183.

Kłósak K., Z teorii i metodologii filozofii przyrody, Księgarnia św. Wojciecha, Poznań 1980.

Kontrowersje wokót początków cztowieka, red. G. Bugajak, J. Tomczyk, Księgarnia św. Jacka, Katowice 2007.

Swoistośćcztowieka? Jezzyk, red. G. Bugajak, J. Tomczyk, Wydawnictwo UKSW, Warszawa 2008.

Swoistość cztowieka? Rozumność, red. G. Bugajak, J. Tomczyk, Wydawnictwo UKSW, Warszawa 2009.

W poszukiwaniu swoistości cztowieka, red. G. Bugajak, J. Tomczyk, Wydawnictwo UKSW, Warszawa 2008.

\title{
IN SEARCH OF THE NATURAL, PHILOSOPHICAL AND THEOLOGICAL IMAGE OF THE UNIVERSE. THE SCIENTIFIC PROFILE OF FR. GRZEGORZ BUGAJAK
}

\begin{abstract}
This article surveys the biography and the most important scientific achievements of Fr. prof. dr hab. Grzegorz Bugajak (1966-2020), associated with the Faculty of Christian Philosophy ATK / UKSW. Fr. Bugajak left a large and interesting scientific output, focusing on problems in the philosophy of nature, philosophy of sciences and the relationship between natural sciences and theology. His works make a significant contribution to the development of philosophy.
\end{abstract}

Keywords: Grzegorz Bugajak; philosophy of nature; science and religion 
Anna Lemańska

Uniwersytet Kardynała Stefana Wyszyńskiego w Warszawie, Instytut Filozofii

(Cardinal Stefan Wyszyński University in Warsaw, Institute of Philosophy, Poland)

ORCID: https://orcid.org/0000-0002-2531-1919

annalemanska@onet.pl

DOI: $10.21697 /$ spch.2020.56.4.03 